IRA-International Journal of Education \& Multidisciplinary Studies

ISSN 2455-2526; Vol.08, Issue 01 (July 2017)

Pg. no. 80-93

Institute of Research Advances

http://research-advances.org/index.php/IJEMS

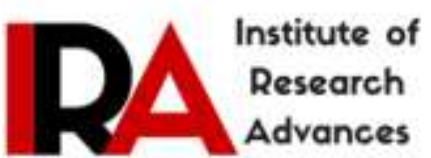

\title{
Peer Instruction in Electromagnetism: The Gender Academic Performance Difference Among Pre-Service Teachers
}

\author{
Aina, Jacob Kola \\ Principal Lecturer, Physics Education Department \\ College of Education (Technical) Lafiagi, Kwara State, Nigeria.
}

Type of Review: Peer Reviewed.

DOI: http://dx.doi.org/10.21013/jems.v8.n1.p9

How to cite this paper:
Aina, Jacob Kola (2017). Peer Instruction in Electromagnetism: The Gender Academic Performance
Difference Among Pre-Service Teachers. IRA International Journal of Education and Multidisciplinary
Studies (ISSN 2455-2526), 8(1), 80-93. doi: http://dx.doi.org/10.21013/jems.v8.n1.p9

(C) Institute of Research Advances.

\section{(c) $\mathrm{EY}-\mathrm{NC}$}

This work is licensed under a Creative Commons Attribution-Non Commercial 4.0 International License subject to proper citation to the publication source of the work.

Disclaimer: The scholarly papers as reviewed and published by the Institute of Research Advances (IRA) are the views and opinions of their respective authors and are not the views or opinions of the IRA. The IRA disclaims of any harm or loss caused due to the published content to any party.

\footnotetext{
Institute of Research Advances is an institutional publisher member of Publishers Inter Linking Association Inc. (PILA-CrossRef), USA. The institute is an institutional signatory to the Budapest Open Access Initiative, Hungary advocating the open access of scientific and scholarly knowledge. The Institute is a registered content provider under Open Access Initiative Protocol for Metadata Harvesting (OAI-PMH).

The journal is indexed \& included in WorldCat Discovery Service (USA), CrossRef Metadata Search (USA), WorldCat (USA), OCLC (USA), Open J-Gate (India), EZB (Germany) Scilit (Switzerland), Airiti (China), Bielefeld Academic Search Engine (BASE) of Bielefeld University, Germany, PKP Index of Simon Fraser University, Canada.
} 


\begin{abstract}
Fifty-two students of a college of education were sampled for this study. The sample comprises of thirty male and twenty-two female pre-service teachers. The quasi-experimental method was employed with the pretestposttest design. Data were collected using Electromagnetism Physics Assessment (EPA). The data gathered were analyzed using Analysis of Variance (ANOVA), descriptive statistics and the independent T-test. The study provided an answer to three research questions. Finding reveals that based on the gender there was no significant difference in academic performance of the pre-service teachers who did not participate in the PI. However, there was a significant difference between male and female pre-service students who took part in the PI. The study has implications for the students teaching and learning of Physics.
\end{abstract}

Keywords: Peer instruction, Conceptual Physics, Problem-solving skill, ConcepTest, Academic performance

\title{
Introduction
}

PI is a research-based pedagogy widely believed to have an influence on the students' conceptual learning in science (Fagen, Crouch and Mazur, 2002). It is a cooperative type of learning where students have enough time to collaborate in learning (Rao and DiCarlo, 2000; Aina, 2016). Peer Instruction is an instructional strategy for engaging students during class through a structured questioning process that involves every student (Crouch, Watkins, Fagen and Mazur, 2007). This instructional approach is different from the traditional cooperative learning because it makes used of the ConcepTest. Conceptest is a short conceptual question posed in a multiple-choice format, on the topic of discussion. The crux of PI is to encourage students to take responsibility for their learning and emphasizes understanding (Gok, 2012).

Electromagnetism is a branch of Physics in the pre-service teacher education in Nigeria that comprises of current electricity and electrostatics (NCCE, 2008). Research studies indicate that this aspect of Physics had been difficult for students to learn for many reasons.

Jaakkola and Nurmi, (2004), Electricity is an important and challenging Physics topic at all school levels where students often have many difficulties in learning electricity. According to McDermott and Shaffer (1993), research studies on electricity revealed that students had difficulties in conceptual understanding. For Urban-Woldron(2013) misconceptions prevent students from getting a firm knowledge of basic concepts in electricity. Engelhart and Beichner (2003) contend that method of instruction does affect students' understanding of concepts in electricity.

Teaching electrostatics is a challenging task due to its complexity and degree of abstraction (Chang, 2007). The abstract nature of electrostatics constitutes considerable difficulties in teaching the subject (Bonham and Risley, 1999).Bertrand (2007) believes it is one of the most difficult areas of Physics to learn and to teach because it is highly abstract in nature.

The matter of gender difference in Physics learning is a controversial issue that requires a careful approach. Otherwise, novices can be misled. Nevertheless, some research studies are worthy of consideration in the light of this study. Crouch and Mazur (2001) observed that there is no gender gap in conceptual understanding of introductory Physics among university students taught with interactive pedagogy. According to Gok (2013), male students performed better than female students in Physics in the area of problem-solving skill.

\section{Purpose of the Study}

The principal objective of the study was to investigate the differences in the academic performance of male and female students in electromagnetism in the PI class. Specifically, the study examined the following:

(1) the different between the scores of male and female students in the pretest and posttest; (2) the different between the scores of male and female students in the pretest and posttest; and (3) the different in academic performance of male and female students in the PI class.

\section{Research questions}

Three research questions were answered by the study. The questions are listed below.

Q1: Is there any gender difference between the pretest and the posttest scores of the pre-service teachers in the control group? 
Q2: Is there any gender difference between the pretest and the posttest scores of the pre-service teachers in the experimental group?

Q3: Is there any gender difference in the academic performance of the pre-service teachers who took part in the PI?

\section{Methodology}

The study is a quasi-experimental of pretest-posttest control group design. According to Best and Kahn (1989), quasi-experimental designs provide control of when and to whom the measurement is applied. Many factors made it impossible for social science researchers to carry out true experiment; however, quasiexperimental designs remain the most widely used design (Ogunniyi, 1992).

All the threats to internal validity are controlled in the pretest-posttest design (Cohen, Manion, and Morrison, 2007). Pretest-posttest designs are widely used primarily to compare groups and measuring change resulting from experimental treatments (Dimitrov and Rumrill, 2003).

\section{Procedure}

The experimental group was subjected to eight weeks of lecturing interspersing lecture method with peer instruction. Twenty adopted electromagnetism ConcepTests from Peer Instruction User's Manual by Mazur (1997) were utilized for the lectures. The pre-service teachers in this group attended two hours lecture every week. The teacher introduces a ConcepTest using a projector and gives two minutes for the students to think about the concepts. After two minutes, students responded to the ConcepTest by flashcards. When the percentage of the correct answer is more than $70 \%$, the teacher gives a brief summary of the ConcepTest and move to another ConcepTest.

When the percentage of the correct answer is less than $70 \%$, the students go into different groups to discuss the answer with their peers. The students are given time to argue out the correct answer in each group. The teacher moves around the class to observe and listen to the students as they argued among themselves. The teacher concludes the argument session with an explanation on the ConcepTest as the case demand. The time for this session was 30 minutes.

Sample

A purposive sampling of fifty-two pre-service teachers who enrolled as Physics students at the Jireh College of Education was sampled. The purposive sample is homogeneous regarding some internal and external factors such as academic background (all have at least a West African Secondary School Certificate in Physics). The rationale for this sampling was that these students were in their introductory level of electromagnetism.

\section{Research Instrument}

In other to generate data for this study, the instrument used in the study was Electromagnetism Physics Assessment (EPA). EPA was made up of conceptual questions and few problem-solving skills questions.

\section{Reliability and Validity}

The reliability of an empirically designed instrument can be defined by the degree to which the collected data can be interpreted consistently across different situations. It may be subjected to various methods such as test-retest and inter-scorer reliability. Before the instrument was administered the inter-scorer method was used whereby raters scored items on a scale of 1 to 5 . This study used inter-scorers reliability which measured the degree of agreement between two or more scorers, judges or raters. Any item scoring an average of 3 or less was discarded. The reliability statistics of the instrument was calculated using SPSS software to get the Cronbach's alpha to be 0.876, according to Pallant (2011), Cronbach's alpha above 0.7 is reliable.

In other to ensure the reliability and validity of the instruments, a pilot study was carried out using preservice Physics teachers in another school different from the participating school. It was done before the commencement of the intervention to assess the validity and appropriate use of the instruments. The EPA was also submitted to a Physics lecturer at a Nigerian University for a thorough scrutinizing before administering it to the students. 


\section{Data Analysis}

The statistical analyses found appropriate for this study are Analysis of Variance (ANOVA), t-test and descriptive statistics analysis. The t-test is a suitable method for comparing the values of some continuous variable for two groups or on two occasions (Pallant, 2011). Descriptive statistical analyses are used for organizing and describing the characteristics of educational variables in concise and meaningful quantifiable terms (Daramola, 2006).

\section{Ethical Considerations}

Before the start of this study, written permission was obtained from each of the participants. The participants took part in the research voluntarily. When the research begins, the participants were made aware as to when, where and how the research will be conducted. The researcher ensured no harm or injury of any form comes to any of the participants as a result of the study.

The dignity and integrity of the participants are necessary and was not violated. Anonymity and confidentiality were respected. For anonymity purpose, the real name of the sampled college was replaced with Jireh College of Education throughout the study

The researcher conducted the research in such a way that there was no favouritism and bias. The researcher granted any participant freedom to withdraw from the research at any stage if he or she feels the need to do so. The researcher ensured a comfortable and conducive atmosphere was maintained for the participants during the research.

\section{Results and Discussion}

Research Question 1: Is there any gender difference between the pretest and the posttest scores of the pre-service teachers in the control group?

The interaction effect is not significant because the significant value of 0.306 is higher than the probability value of .05 as seen in Table 1.This implies students' scores in the pretest has no effect on the scores in the posttest. The main effect is also not significant with a significant value of 0.864 higher than the probability value of .05. This implies the change in students' score due to gender is not significant. Table 2 indicates there was no significant effect of sex on the students' score with the significant value of 0.953 higher than the probability value of 0.05 .

Research Question 2: Is there any gender difference between the pretest and the posttest scores of the preservice teacher in the experimental group?

The interaction effect according to the Table 3 was not significant with the value of 0.057 slightly higher than the probability value of 0.05 . The main effect is not significant with 0.135 , greater than the 0.05

Table 4 shows a significant effect of sex on the students' scores with the significant value of 0.045 , less than the probability value of 0.05 . This implies that gender has an influence on the use of PI in electromagnetism class.

Research Question 3: Is there any gender difference in the academic performance of the pre-service teachers who took part in the PI?

Table 5 shows the percentage scores of male and female in electromagnetism in the EPA after the intervention. Figure 2 shows the scores distribution among the students based on gender. The lowest mark recorded in electromagnetism was among both male and female students. However, the number of students with the highest score was recorded among the male students as revealed by figure 2 .

Table 6 shows non-violation of the assumption of equal variance because the significant value of 0.970 is greater than the probability value of 0.05 . The t-test for the equality of mean value has 0.030 (2-tailed) which is less than the probability value of 0.05 : this implies that there is a significant difference between the male and female students who attended the PI class. The calculated eta square of 0.18 (18\%) indicates that the effect size is large.

Table 7 indicates that male students are better academically in current electricity than the female students. The general analysis indicates a significant difference between the male and female academic performance in electromagnetism. The mean difference in students' academic performance in electricity, an aspect of 
electromagnetism shows a wide gap in performance. The gap is very wide in questions eight and nine, female student scores zero, and the male students had mean scores of 2.7 and 8.0 respectively. The table also shows that male students were better academically in electrostatics than the female students.

Analysis of conceptual question from the Table 8 indicates that male is superior in academic performance to the female students. Female students scored zero in three conceptual questions. The analysis is further explained by the figure 3 .

Male student shows superiority over female students in the problem-solving skill questions as shown in Table 8. This outcome is consistent with Gok (2012) that male student is better in academic performance in problem-solving skill in Physics than the female student.

\section{Discussion}

Hazari and Potvin (2005) explained that female students do not show interest in physical science,especially Physics. Interest is important in learning; once a student lost interest in a subject, he/she may no longer do well in such subject. Aina and Adedo (2013) have once attributed low enrolment in science subject like Physics to lack of interest. Research also suggests the rate of attrition in Physics is higher among female students (Hazari, Tai, and Sadler, 2007). The outcome of this study is consistent with Stephen (2010) that male students are proved through research to have a higher manipulative ability than their female counterparts (p.155). The study indicates a wide gap in academic performance between male and female students who participated in the PI intervention. This is evidence of a large size effect of calculated eta square. This outcome is relevant to Gok (2014) that teaching with interactive strategies increases the comprehension of both genders but that more study is required on the gender differences in Physics education.

Because of the lack of interest students shun sciences particularly Physics when given an option, and this especially applies to girls (Olufunke, 2012).Opinion differs as regards to male and female performance in Physics. However, there are studies with evidence of differences in enrollment and performance in Physics between male and female (Hazari and Potvin, 2005; Semola, 2010; Greeberg, 2006). The present study is consistent with volumes of studies as regards the superiority of male students to female in academic performance in Physics. However, the causes of this difference are more germane at this point.

Some of the reasons the female students were behind male students in academic performance in Physics as indicated by research studies are interest, academic self-concept, attitude, and socio-cultural.

Research abounds that students do better on any subject they show interest. Many female students have not been showing good interest in learning science including Physics in schools today. These students enrolled for Physics because it is a requirement that must be satisfied before graduating in other courses. According to Garwin and Ramsier (2003), interests in learning Physics is decreasing among students in higher school and subsequently result in low achievement in the subject. Olufunke contended that students' interest would determine what they can learn and how well they may learn. According to this author, interest also determines how well a student can apply what he or she has learned. Thus, Taale (2013) suggests that Physics teachers should make Physics interesting to the students using a variety of teaching and learning strategies.

Agbaje and Alake (2014) in their study on "The student variables as a predictor of secondary school students' academic achievement in science subjects" concluded that students' interest is vital to learning. Agbaje and Alake concurred that students' interest and attitude are crucial to academic performance in Physics.

Due to lack of interest in Physics by many female students, they, therefore, show negative attitudes to the subject. Negative attitude to Physics by female students has resulted in the poor academic performance of the students (Thomas and Israel, 2013). Teachers alike demonstrated negative attitudes toward the female students having the notion they do not have the ability to study Physics. Whyte (1986) explain that some teachers have the attitude that a girl-child cannot do well in mathematics and the abstract nature of Physics is well beyond them. Victoria (2011) faulted the teacher for failing to inculcate in the female learners the critical thinking to make studying Physics easy.

Research has shown that students' interest will make them study and learn Physics better and, choose to study Physics as a course at the higher level of education (Lavonen, Byman, Juuti, Meisalo, \& Uitto, 2005). The study conducted by Lavonen et al., on pupil interest in Physics in Finland, indicates that girls' interest in Physics is lower than that of the male. This study is consistent with Hoffmann's (2002) that male students have an interest in Physics lessons than their female counterparts. 
Physics is traditionally regarded is male subject. Limprecht, Janko \& Gläser-Zikuda (2013) cited Milhoffer (2000) that female students rate their abilities and performance on a lower level compared to male students. Wodzinski (2007) Physics teacher instruction is predominantly related to the learning demands of boys which probably caused the girls to feel rather insecure in Physics lessons and fear Physics as a subject. According to Limprecht, Janko \& Gläser-Zikuda, this may have impacted the girls to underestimate their learning achievement in Physics. To Lupart, Cannon, \&Telfer (2004), the girls have a tendency to underestimate their competencies.

Hoffmann asserted that girls grow old and find Physics as a school subject to be less and less attractive. The author observed that research shows that Germany girls get less support and encouragement from their parents to work in the areas of Physics.

Self-concept is an educational construct that is critical to students' success in any subject. Self-concept is the perception a student has about his or herself. The moment a student has the perception that he cannot succeed in any subject based on any reason best known to him or her it may be difficult to change such student. Clarke (2005) argued that how a student perceives his or her ability can hinder or enhance his/her learning experience. According to Dupe (2013), the way a learner feel about his/her abilities may impact his/her academic performance. Another educational construct is self-efficacy. Bandura (1986), a proponent of social learning theory describes self-efficacy as the set of beliefs a person holds regarding his or her capabilities to produce desired outcomes and influence events that affect his or her life. Kpolovie, Joe, and Okoto (2014) asserts that many of the factors that influence students learning might include self-efficacy, students ‘ attitude towards school, interest in learning, and study habit.

Many of the female students in Physics have a low self-efficacy because they lacked self-concept. Dupe views the academic concept as an individual's perception of self-efficacy in a subject. A female student with high self-efficacy will persist in her study even in the face of learning difficulties. A female student who has low self-efficacy will not be willing to go the extra mile in his or Physics learning. Beside self-efficacy, socio-cultural issues are another strong factor that inhibits female academic performance in Physics.

Aina (2014) explains that some of the causes of poor performance among female Physics students in Nigeria are religion and early marriage. In Nigeria, a particular religion prohibits formal education for female children: any female who defies this religion prohibition does that at her risk. Many of these female students are always psychologically imbalance because of fear. Norton and Tomal (2009) reported that religion adversely affects female education. Due to early marriage in some part of the Nigeria, it is very common to see a female student in Physics class nursing a child. The researcher had witnessed students in Physics class nursing children, and this is worrisome because such students always dropped out of Physics class as a result of poor academic performance. These students already had divided attention to learning and their babies. There is the burden of child rearing and that of reading about a girl who has put to bed while in school. International Labour Organization [ILO] put it this way:

Women and girls often spend significantly more time on household chores and caring duties, such as child-rearing or attending to the sick, than do their male counterparts. The obligation to undertake household chores inevitably limits the time available for education and other activities (p.20).

Therefore, it should not be strange to anyone if male students are academically better than the female students in Physics. Therefore, the present study indicates that there was a significant difference between male and female students' academic performance in Physics and the size effect was large.

\section{Summary of the Findings}

An Analysis of Variance was performed for both the control and experimental groups. Both the interaction effect and main effects were not statistically significant. An independent-samples t-test was also conducted to compare the academic performance of male and female students. There was a significant difference in scores for males $(M=38.40, S D=12.25)$ and females $(M=27.27, S D=11.91 ; t(24)=2.31, p=$ 0.03, two-tailed). The magnitude of the differences in the means (mean difference $=11.13,95 \%$ CI: 1.20 to 21.05 ) was large (eta squared $=.18$ ).

Given the results of the different analysis, a significant difference exists between the male and female students academic performance after the PI intervention. The finding indicates there was no difference in the academic performance of the pre-service teachers who did not participate in the PI. Besides, there was a 
significant difference between male and the female academic performance after the PI intervention with a large size effect. The male student shows superiority over the female students in current electricity and electrostatics. The finding also indicates that male students were better than female students in both the conceptual and problem-solving skills in electromagnetism.

The following conclusion was reached.

1. There was no gender influence on the academic performance of the pre-service teachers who did not participate in the PI

2. A significant difference exist between male and female academic performance in electromagnetism

3. Male pre-service teachers are academically better than their female counterparts in both current electricity and electrostatics and

4. Male pre-service teachers are academically superior to the female pre-service teachers both in the conceptual Physics and problem-solving skill in Physics.

\section{The Implications of the Study}

The study had a paradigm of interactive engagement where both male and female students were grouped together for learning purpose. Naturally, female students are very reserved when it comes to interaction. Most female students preferred interacting with students of the same gender. During this study, male students were more active in the group discussion irrespective of the number of male in the group.However, the female students were more active in any group where there are more female students throughout the study. Finding reveals that there was no significant different in academic performance based on gender in the student at control group. Thus, the difference existing based on the gender in the experimental group was likely due to the process of PI due to the students' interaction. The implication is that for the success of the PI in science class, grouping should be done according to gender. This could help the female students to be more active during learning and assist them to interact well.

\section{References}

1. Agbaje, R.O., \& Alake, E.M. (2014). Students' variables as predictor of secondary school students' academic achievement in science subjects. International Journal of Scientific and Research 4(9), 1-5.

2. Aina, J.K., \& Adedo, G.A. (2013). Correlation between continuous assessment (CA) and students' performance in Physics. Journal of Education and Practice, 4(6), 6-9.

3. Aina, J.K. (2014). Effect of socioeconomic and socio-cultural barrier on female education: implications for students' enrolment and learning in Physics. International Journal of Modern Education Research, 1(4), 73-77.

4. Aina, J.K. (2016). Using peer instruction (PI) to investigate pre-service Physics teachers Academic performance in Nigeria. Journal of Scientific and Engineering Research, 3(4), 6-15.

5. Bandura, A. (1986). Social foundations of thought and action: Asocial cognitive theory. Englewood Cliffs, NJ: Prentice-Hall.

6. Bertrand, P. (2007).A Note from the Editor. In P. Bertrand (ed). Special Focus: electrostatics (p.3). AP Physics: AP Central.

7. Best, J.W., \& Kahn, J.V. (1989). Research in education (6 ${ }^{\text {th }}$ ed.). India: Prentice-Hall.

8. Bonham, S.W., Risley, J.S., \& Christian, W. (1999). Using Physlets to teach electrostatics.The Physics Teacher, 57, 276-281.

9. Chang, W. (2007, June). Integrating Electrostatics with Demonstration and Interactive Teaching. Paper presented to the Ninth International History, Philosophy \& Science Teaching Conference. Calgary, Canada.

10. Cohen, L., Manion, L., \& Morrison, K. (2007).Research Methods in Education. New York: Routledge

11. Clarke, R.J. (2005). Research Models and Methodologies. HDR Seminar Series. Retrievedfromhttps://www.uow.edu.au/content/groups/.../uow012042.pdperformance. Journal of College Teaching \& Learning, 5(11), 49-57

12. Crouch, C.H., \& Mazur, E. (2001). Peer instruction: Ten years of experience and results. American Journal of Physics, 69(9), 970-977

13. Crouch, C.H, Watkins,J.,Fagen, A.P. \& Mazur, C. (2007). Peer Instruction: Engaging students oneon-one, all at once. Research-Based Reform of University Physics. Retrieved from www.mazur.harvard.edu/sentFiles/Mazurpubs_537.pdf.

14. Daramola S.O. (2006). Research and statistical methods in education. Students and Researchersin Tertiary Institutions. Ilorin, Nigeria; Bamitex. 
15. Dimitrov D.M. \& Rumrill, P.D. (2003). Pretest-posttest designs and measurement of change. Speaking of Research. Retrieved from www.ncbi.nlm.nih.gov/pubmed/12671209.

16. Dupe, O.B. (2013). Predicting students' achievement in Physics using academic self-concept and locus of control scale scores. International Journal of Social Science and Education, 3(4), 1149-1155.

17. Engelhardt, P.V., \& Beichner, R.J. (2003). Students' understanding of direct current resistive electrical circuits. American Journal of Physics, 72(1), 98-115.

18. Fagen, A.P., Crouch, C.H., \& Mazur, E. (2002). Peer instruction: Results from a range of classroom. The Physics Teacher, (40), 206-209.

19. Garwin, M.R. \& Ramsier, R.D. (2003). Experiential learning at the university level: A U.S case study. Education and Training, 45(5), 280-285.

20. Gok, T. (2012). The Impact of peer instruction on college students beliefs about Physics and conceptual understanding of electricity and magnetism. International Journal of Science and Mathematics Education, 10(2011), 417-437.

21. Gok, T. (2013). A comparison of students' performance, skill and confidence with peer instruction and formal education. Journal of Baltic Science Education, 12(6), 747-758

22. Gok, T. (2014). Peer instruction in the Physics classroom: effects on gender difference performance, conceptual learning, and problem-solving. Journal of Baltic Science Education, 13(6), 776-788

23. Greenberg, E.I. (2006) Identifying Gender Gaps Learning Growth in Physics. Instructional Technology monograms. Retrieved from http://projects.coe.uga.edu/itm/achieves/fall 2005/egreenberg.htm.

24. Hazari, Z \& Potvin, G (2005). Views on female under-representation in Physics: Retaining women or reinventing Physics? Electronic Journal of Science Education, 10(1), 1-33

25. Hazari, Z., Tai, R.H., \& Sadler, P.M. (2007). Gender Differences in Introductory University Physics Performance: The Influence of High School Physics Preparation and Affective Factors. Science Education, 847-876. DOI 10.1002/sce.

26. Hoffman, L. (2002). Promoting girls' interest and achievement in Physics classes for beginners. Learning and Instruction, 12, 447-465.

27. Jaakkola, T., \&Nurmi, S. (2004,September). Academic impact of learning objects: the case of electric circuits. Paper presented at the British Educational Research Association annual conference, Manchester.

28. Lavonen, J., Byman, R., Juuti, K., Meisalo, V.,\&Uitto, A. (2005). Pupil interest in Physics: A survey in Finland. NORDINA. http://roseproject.no/network/countries/finland/finlavonen-nordina2005.pdf

29. Limprecht, S., Janko, T., \& Gläser-Zikuda, M. (2013). Achievement emotions of boys and girls in Physics instruction: Does a portfolio make a difference? OrbisScholae, 7(2) 43-66.

30. Lupart, J. L., Cannon, E., \&Telfer, J. A. (2004). Gender differences in adolescent academic achievement, interests, values and life-role expectations. High Ability Studies, 15(1), 25-42.

31. Mazur, E. (1997). Peer instruction: a user's manual. Upper Saddle River: Prentice Hall.

32. McDermott, L., \& Shaffer, P. (1993). Research as a guide for curriculum development: An example from introductory electricity. Part I: Investigation of student understanding. American Journal of Physics, 60, 994-1003 (erratum 61, 81).

33. Milhoffer, P. (2000). Wiesiesichfühlen, was siesichwünschen. Eineempirische StudieüberMädchen und Jungen auf demWeg in die Pubertät. Weinheim: Juventa.

34. NCCE. (2008). National Commission for Colleges of Education minimum standard ( $3^{\text {rd }}$ Ed), Kaduna: Government Press.

35. Norton, S.W \&Tomal, A. (2009). Religion and female educational attainment. Journal of Money, Credit and Banking, 41(5), 961-986.

36. Ogunniyi, M. B (1992). Understanding research in the social sciences. Ibadan: The University Press

37. Olufunke, B.T. (2012). Effect of availability and utilization of Physics laboratory equipment on students' academic achievement in senior secondary school Physics. World Journal of Education, 2(5), $1-7$.

38. Pallant, J. (2011). SPSS survival manual. A step by step guide to data analysis using SPSS (4 ${ }^{\text {th }}$ ed.). Australia: Allen \& Unwin.

39. Rao, S. P., \& DiCarlo, S. E. (2000). Peer instruction improves performance on quizzes. Advances in Physiology Education, 24(1), 51-55.

40. Semola, T (2010). Who is joining Physics and why? Factors influencing the choice of Physics among Ethiopian University students. International Journal of Environmental and Science Education, 5(3), 319-340.

41. Stepnen, U.S (2010).Technological attitude and academic achievement of Physics students in secondary schools. African Research Review, 4(3a), 150-157 
42. Taale, K.D. (2013). Remediating some learning difficulties of L200 science education students of ModibboAdamaUniversity of Technology in some Physics concepts using multiple representations. International Journal of Education and Practice, 1(3), 26-43.

42. Thomas, O. O. \& Israel, O.O. (2013). Assessing the relative effectiveness of three teaching methods in the measurement of students ' achievement in Physics.International Journal of Materials, Methods and Technologies, 1(8), 116-125.

43. Urban-Woldron, H. (2013).Testing student conceptual understanding of electric circuits as a system.Retrievedfromhttps://www.esera.org/media/eBook_2013/strand\%2011/ESERA_Proceedings_ Testing_student_conceptual_understanding_of_electric_circuits_as_a_system.pdf

44. Victoria, M.B. (2011). Factors contributing to underachievement of Zambian female studentsin OLevel Physics examination. A case of selected high schools in central province (Master thesis). Retrieved from http://dspace.unza.zm:8080/xmlui/bitstream/handle/123456789/1901/Preliminary\%20Pages.pdf?seque nce $=1$.

45. Whyte, J. (1986). Girls into science and technology: the story of a project. London:Routledge and Kegan.

46. Wodzinski, R. (2007). Mädchenim Physikunterricht. In E. Kircher, R. Girwidz, \& P. Häußler (Hrsg.), Physikdidaktik. Theorie und Praxis (pp. 559-580). Berlin, Heidelberg: Springer.

TABLES \& FIGURES SECTION

Table 1

Multivariate Tests

\begin{tabular}{|c|c|c|c|c|c|c|}
\hline Effect & & Value & $\mathrm{F}$ & Hypothesis df & Error df & Sig. \\
\hline \multirow{4}{*}{ student_scores } & Pillai's Trace & .044 & $1.095^{\mathrm{b}}$ & 1.000 & 24.000 & .306 \\
\hline & Wilks' Lambda & .956 & $1.095^{\mathrm{b}}$ & 1.000 & 24.000 & .306 \\
\hline & $\begin{array}{l}\text { Hotelling's } \\
\text { Trace }\end{array}$ & .046 & $1.095^{\mathrm{b}}$ & 1.000 & 24.000 & .306 \\
\hline & $\begin{array}{l}\text { Roy's Largest } \\
\text { Root }\end{array}$ & .046 & $1.095^{\mathrm{b}}$ & 1.000 & 24.000 & .306 \\
\hline \multirow{4}{*}{$\begin{array}{l}\text { student_scores } \\
* \text { sex }\end{array}$} & Pillai's Trace & .001 & $.030^{\mathrm{b}}$ & 1.000 & 24.000 & .864 \\
\hline & Wilks' Lambda & .999 & $.030^{\mathrm{b}}$ & 1.000 & 24.000 & .864 \\
\hline & $\begin{array}{l}\text { Hotelling's } \\
\text { Trace }\end{array}$ & .001 & $.030^{\mathrm{b}}$ & 1.000 & 24.000 & .864 \\
\hline & $\begin{array}{l}\text { Roy's Largest } \\
\text { Root }\end{array}$ & .001 & $.030^{\mathrm{b}}$ & 1.000 & 24.000 & .864 \\
\hline
\end{tabular}


Table 2

Tests Between-Subjects Effects

\begin{tabular}{|c|c|c|c|c|c|}
\hline Source & $\begin{array}{l}\text { Type III } \\
\text { Sum of } \\
\text { Squares }\end{array}$ & $\mathrm{df}$ & $\begin{array}{l}\text { Mean } \\
\text { Square }\end{array}$ & $F$ & Sig. \\
\hline Intercept & 35453.203 & 1 & 35453.203 & 214.071 & .000 \\
\hline Sex & .588 & 1 & .588 & .004 & .953 \\
\hline Error & 3974.739 & 24 & 165.614 & & \\
\hline
\end{tabular}

Table 3

Multivariate Tests ${ }^{b}$

\begin{tabular}{llccccc}
\hline Effect & & Value & F & $\begin{array}{c}\text { Hypothesis } \\
\text { df }\end{array}$ & Error df & Sig. \\
& & & & & \\
& Pillai's Trace & .142 & $3.988^{\mathrm{b}}$ & 1.000 & 24.000 & .057 \\
student_scores & Wilks' Lambda & .858 & $3.988^{\mathrm{b}}$ & 1.000 & 24.000 & .057 \\
& $\begin{array}{l}\text { Hotelling's } \\
\text { Trace }\end{array}$ & .166 & $3.988^{\mathrm{b}}$ & 1.000 & 24.000 & .057 \\
& $\begin{array}{l}\text { Roy's Largest } \\
\text { Root }\end{array}$ & .166 & $3.988^{\mathrm{b}}$ & 1.000 & 24.000 & .057 \\
& $\begin{array}{l}\text { Pillai's Trace } \\
\text { Student_scores* sex }\end{array}$ & .091 & $2.398^{\mathrm{b}}$ & 1.000 & 24.000 & .135 \\
& $\begin{array}{l}\text { Wilks' Lambda } \\
\text { Hotelling's }\end{array}$ & .909 & $2.398^{\mathrm{b}}$ & 1.000 & 24.000 & .135 \\
& $\begin{array}{l}\text { Trace } \\
\text { Roy's Largest } \\
\text { Root }\end{array}$ & .100 & $2.398^{\mathrm{b}}$ & 1.000 & 24.000 & .135 \\
& & .100 & $2.398^{\mathrm{b}}$ & 1.000 & 24.000 & .135 \\
\hline
\end{tabular}

Table 4

Tests Between-Subjects Effects

\begin{tabular}{|c|c|c|c|c|c|}
\hline Source & $\begin{array}{l}\text { Type III } \\
\text { Sum of } \\
\text { Squares }\end{array}$ & $\mathrm{df}$ & $\begin{array}{l}\text { Mean } \\
\text { Square }\end{array}$ & $\mathrm{F}$ & Sig. \\
\hline Intercept & 45696.923 & 1 & 45696.923 & 357.291 & .000 \\
\hline Sex & 574.923 & 1 & 574.923 & 4.495 & .045 \\
\hline Error & 3069.558 & 24 & 127.898 & & \\
\hline
\end{tabular}




\section{Table 5}

Male and Female Performance in Electromagnetism

\begin{tabular}{lll}
\hline S/n & Male (\%) & Female (\%) \\
\hline 1 & 31 & 38 \\
2 & 46 & 46 \\
3 & 54 & 31 \\
4 & 38 & 38 \\
5 & 46 & 31 \\
6 & 54 & 08 \\
7 & 23 & 31 \\
8 & 31 & 23 \\
9 & 38 & 08 \\
10 & 46 & 23 \\
11 & 38 & 23 \\
12 & 08 & \\
13 & 46 & \\
14 & 46 & \\
15 & 31 & \\
\hline
\end{tabular}

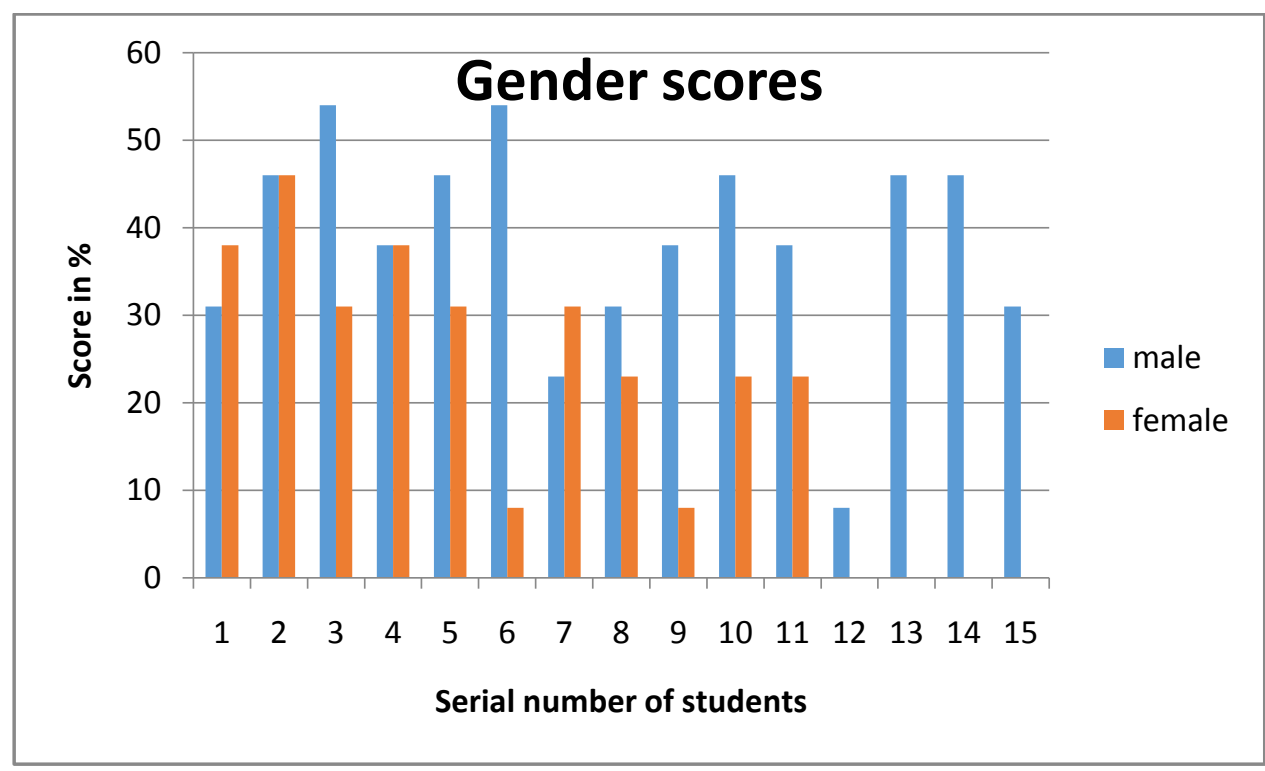

Figure 1: Score in EPA based on gender 


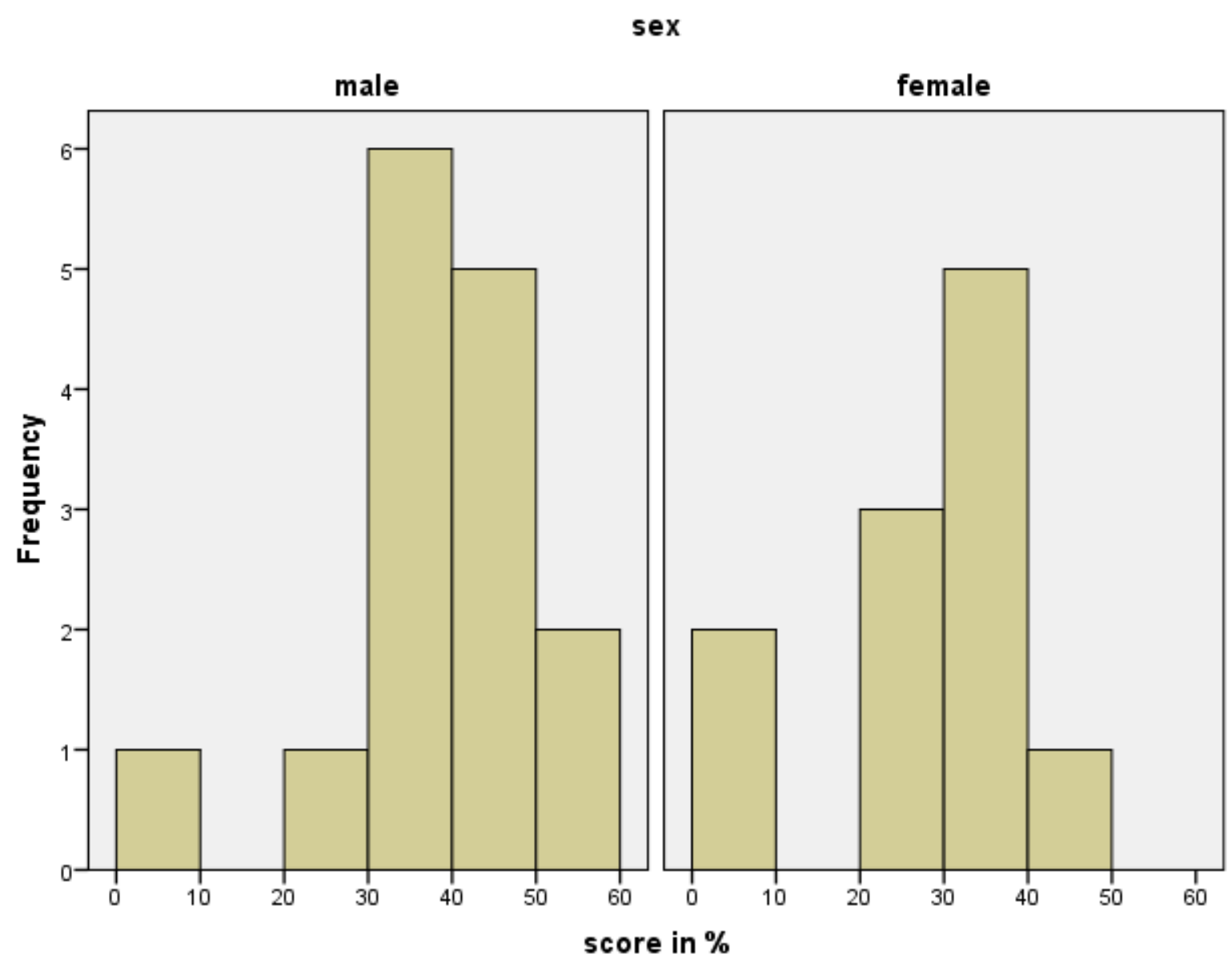

Figure 2. Gender score in EPA frequency distribution.

Table 6

T-test Analysis

\begin{tabular}{|c|c|c|c|c|c|c|c|c|c|c|}
\hline & & \multicolumn{6}{|c|}{ Levene's Test for Equality of Variances } & \multicolumn{3}{|c|}{ t-test for Equality of Means } \\
\hline & & \multirow[t]{2}{*}{$\mathrm{F}$} & \multirow[t]{2}{*}{ Sig. } & \multirow[t]{2}{*}{$\mathrm{T}$} & \multirow[t]{2}{*}{ Df } & \multirow[t]{2}{*}{$\begin{array}{l}\text { Sig. (2- } \\
\text { tailed) }\end{array}$} & \multirow[t]{2}{*}{$\begin{array}{l}\text { Mean } \\
\text { Diff }\end{array}$} & \multirow[t]{2}{*}{$\begin{array}{l}\text { Std. } \\
\text { Error } \\
\text { Diff }\end{array}$} & \multicolumn{2}{|c|}{$\begin{array}{l}95 \% \text { confidence } \\
\text { interval of the } \\
\text { difference }\end{array}$} \\
\hline & & & & & & & & & Lower & Upper \\
\hline & $\begin{array}{l}\text { Equal } \\
\text { variances } \\
\text { assumed }\end{array}$ & 0.01 & .970 & 2.31 & 24 & .030 & 11.13 & 4.809 & 1.203 & 21.052 \\
\hline $\begin{array}{l}\text { Scor } \\
\text { e }\end{array}$ & $\begin{array}{l}\text { Equal } \\
\text { variances } \\
\text { not } \\
\text { assumed }\end{array}$ & & & 2.32 & 22.049 & .030 & 11.13 & 4.787 & 1.200 & 21.054 \\
\hline
\end{tabular}


Table 7

Mean Scores of Students in Current Electricity and Electrostatics

\begin{tabular}{llllll}
\hline \multicolumn{2}{c}{ Current Electricity } & \multicolumn{3}{c}{ Electrostatics } \\
\hline Question & Male (N= 15) & Female (N= 11) & Question & Male (N=15) & Female (N=11) \\
\hline 2 & 2.0 & 1.8 & 1 & 6.7 & 4.6 \\
3 & 1.3 & 2.0 & 6 & 4.0 & 0.0 \\
4 & 4.7 & 1.8 & 10 & 3.3 & 1.8 \\
5 & 5.3 & 2.7 & 13 & 2.7 & 3.6 \\
7 & 5.3 & 1.8 & & & \\
8 & 2.7 & 0.0 & & & \\
9 & 8.0 & 0.0 & & & \\
11 & 2.7 & 2.0 & & & \\
12 & 5.3 & 2.7 & & & \\
\hline
\end{tabular}

Table 8

Mean Scores of Students in Conceptual Question and Problem-solving Skill

\begin{tabular}{llllll}
\hline Conceptual & \multicolumn{5}{l}{ Problem-solving Skill } \\
\hline Question & Male (N=15) & Female (N=11) & Question & Male (N=15) & Female (N=11) \\
\hline 1 & 9.1 & 4.5 & 11 & 2.7 & 1.8 \\
2 & 2.0 & 1.7 & 12 & 5.3 & 2.7 \\
3 & 1.3 & 1.8 & 13 & 2.7 & 3.6 \\
4 & 4.7 & 1.7 & & & \\
5 & 5.3 & 2.7 & & & \\
6 & 4.0 & 0.0 & & & \\
7 & 5.3 & 1.7 & & \\
8 & 2.7 & 0.0 & & & \\
9 & 8.0 & 0.0 & & & \\
10 & 3.3 & 1.7 & & & \\
\hline
\end{tabular}




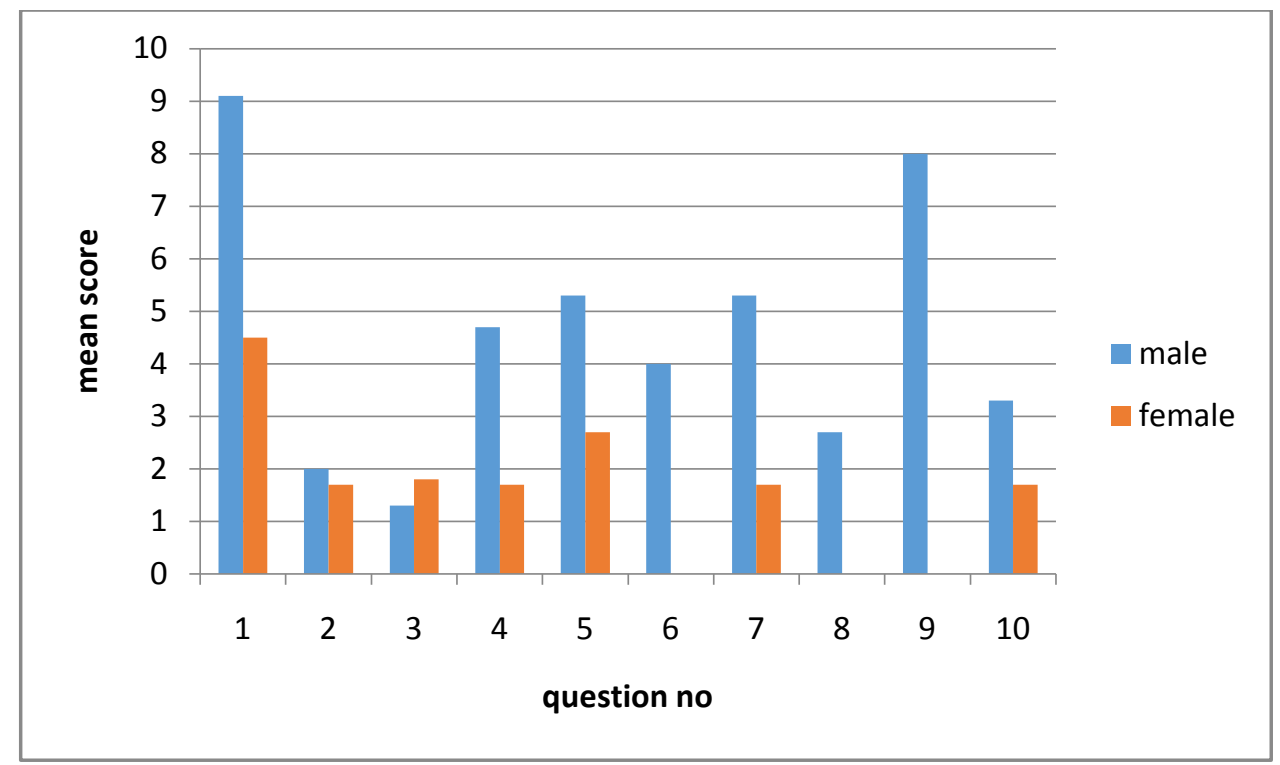

Figure 3. Chart of students' achievement in conceptual questions 